\title{
An Unfolding Signifier: London's Baltic Exchange in Tallinn
}

Stuart Burch, Nottingham Trent University

\begin{abstract}
In the summer of 2007 an unusual cargo arrived at Muuga and Paldiski harbors outside Tallinn. It consisted of nearly 50 containers holding over 1,000 tons of building material ranging from marble columns, staircases and fireplaces, to sculpted allegorical figures, wooden paneling and old-fashioned telephone booths. They were once part of the Baltic Exchange in the City of London. Soon they will become facets of the landscape of Tallinn. The following article charts this remarkable story and deploys this fragmented monument to analyze three issues relating to the Estonian capital: the relocation of the 'Bronze Soldier', the demolition of the Sakala Culture Center, and Tallinn’s future role as European Cultural Capital in 2011.
\end{abstract}

\section{Key words}

Baltic Exchange, Estonia, heritage, London, monument, Roland Barthes, Tallinn, urban landscapes

\section{Figures}

Figure 1 Baltic Exchange façade [only included in the printed version].

Figure 2 Baltic Exchange trading hall with J.D. Forsyth's stained-glass windows in situ [only included in the printed version].

Figure 3 St Ethelburga's Centre for Reconciliation and Peace plus 30 St Mary Axe - 'the Gherkin' - in the background [author's own].

Figure 4 Proposed site in Tallinn for the Baltic Exchange [author's own]. 


\section{Introduction}

The ostensible subject of this paper is the building known as the Baltic Exchange. It was erected in London at the start of the twentieth century and blown up by the Irish Republican Army in 1992. The salvaged remains were recently bought by two Estonian businessmen with the intention of reconstructing the building in Tallinn. The structure is now in Estonia, although construction work had not yet begun at the time of writing.

This article capitalizes on this liminal moment to explain how and why the Baltic Exchange building has ended up in the Estonian capital - and what consequences its presence might have there. It explores various issues raised by this nomadic monument. The first half of the paper, which seeks to establish the history of the building leading up to its removal to Estonia, focuses on the heritage debates that took place in London over whether to rebuild, remove or replace the damaged building. By bringing this 'external' case study to bear on the Baltic region it is hoped that light will be cast on the most important focus of this article: namely the contested landscape of contemporary Tallinn.

As with many of the papers in this special issue of the Journal of Baltic Studies, this article found its origin in the conference 'Places of Commemoration in North-Eastern Europe: National - Transnational - European?' My contribution was to provide a concluding comment on the issues that had been raised by the preceding speakers. It sought to draw parallels between the conference's main themes through recourse to a comparative example: the Baltic Exchange. The wide-ranging and open-ended nature of my presentation extends to this written version. It needs to be read in conjunction with the two papers published here that deal with the 'Bronze Soldier' war memorial in Tallinn. For, whilst my text does not address this monument directly it has in fact 
provided the paper's principal motivation. The violent response to its removal revealed with shocking clarity the vital importance of urban symbolism. The riots in Tallinn of April 2007 places an onus on the academic community to investigate why a sign such as the Bronze Soldier is so contentious, explain what factors led to such violent protests and draw far-reaching conclusions from these findings.

The opening section of this paper seeks to aid this endeavor by providing a theoretical framework for analyzing material culture. It focuses on the work of French social theorist Roland Barthes, in part because his prophetic words were spoken exactly forty years before the upheaval surrounding the Bronze Soldier. Such anniversal moments are always significant. They serve to thrust the past into the present, reframing the latter and revealing again and again how history is a contemporary, constructed phenomenon. ${ }^{1}$

Some readers will object to this hackneyed focus on Barthes. I, however, concur with the view that Barthes remains a 'crucial figure in modern literary and cultural theory' (Allen 2003: 1). One preeminent instance of his enduring appeal is James S. Duncan’s brilliant book The City as Text (1990). Duncan's study takes up Barthes' recommendation to 'read the city' in a manner that embraces a diverse range of 'voices' (Duncan 1990: 17). It shows the enormous benefits that can be reaped when cultural landscapes are construed as entities capable of being read in a myriad of multiple ways.

This, however, can only be achieved by taking into consideration competing 'accounts' (Duncan 1990: 17-19). Thus the approach adopted here is deliberately expansive and overtly non-hierarchical. It espouses the notion that cities are constituted by an overlapping and competing amalgam of different interlocutors from the theorist to the politician, the heritage professional to the interested resident. 
They identify different aspects of the landscape and reference other times and places to support their point of view. Cities are emphatically not read in a linear, chronological fashion by a prescribed number of commentators. They are as much a product of contest as they are consensus. The proposed insertion of London's Baltic Exchange in Tallinn enunciates this in a particularly striking fashion.

This article responds with alacrity to Roland Barthes' call to make cities 'sing'. It ends on a polemical note. For the Baltic Exchange provides a means of thinking about heritage as a creative, future-driven phenomenon. This, I seek to argue, needs to be a central component of Tallinn's plans for 2011, the year when the Estonian capital will serve as a European City of Culture. The Baltic Exchange can and should play a central role in this event. In doing so it will provide one means of escaping from the otherwise interminable morass opened up by the Bronze Soldier debacle.

This paper is therefore addressed as much to the academic community as it is the organizers of the 2011 celebration and those with an interest in the built environment of Tallinn and other capital cities in the Baltic region. It aims to provide a theoretically informed contribution to current events - one that embraces the aims and scope of the Journal of Baltic Studies by providing a novel and unusual contribution to the scholarly understanding of an important aspect of the Baltic Sea Region's political and cultural life.

\section{Urban symbols and unfolding signifiers}

There is 'a growing awareness of the functions of symbols in urban space'. So said the French social theorist Roland Barthes (1997a: 167) in a speech given at the University of Naples in May 1967. Events in Tallinn exactly 40 years later suggest that such attention is more intense than ever. This article seeks to demonstrate that, 
despite the passing of four decades, Barthes' comments on symbols and urban space remain both highly topical and instructive today.

Barthes (1915-80) was a 'semiologist' or 'specialist in signs' (Barthes 1997a: 166). His extensive publications combined a passion for written language with a broader interest in 'the way in which objects can signify in the contemporary world' (Barthes 1988: 180). His studies confirm that material culture can be 'read' like a written text (Tilley et al 2005: 7). Indeed, tangible objects constitute a readily accessible introduction to semiology (also known as semiotics). ${ }^{2}$

In 1916, Ferdinand de Saussure (1966: 16) defined semiology as a 'science that studies the life of signs within society'. A sign is made up of a signifier and a signified. The former is the material aspect of the sign - a sound, a written mark or an actual object. The signified is the mental concept that it generates. In his Naples talk, Barthes (1997a: 168-9) argued forcefully that it was wrong to assume 'a regular correspondence between signifiers and signifieds' and discounted any notion 'of a one-to-one symbolism’.

He made these comments whilst advocating the notion that urban space is in fact a 'discourse' or 'language'. Rather than embarking on a misguided search for the ultimate meaning of an urban symbol, he argued, one ought instead to acknowledge that the city structure is 'a play of signs' that can only be understood by being left open (Barthes 1997a: 172). A 'semantic approach to the city' should therefore seek to 'unfold the signifier'.

Barthes (1997a: 171) continued that, because cities are not read in a conventional manner, steps should be taken 'to multiply the readings of the city'. Like his compatriot, Michel de Certeau (1984), he felt that cities were written as they were read. It is the reader - 'the user of the city (what we all are)' (Barthes 1997a: 170) - 
that actualizes it. Metaphorically speaking, the city is, as a result, less like a single book and more akin to a whole library (cf. Barthes 1997a: 170). And Barthes (1988: 186) similarly cautioned that, whilst the individual components of an urban landscape - such as its monuments - might seem like individual words written on the pages of the city, 'that would be an inexact comparison, for the isolated object is already a sentence'.

For Barthes all texts - including city-texts - are 'worked out in a perpetual interweaving' (Barthes 1990: 64). An additional term he deployed to characterize this 'interweaving' was 'texture', a word also used by another of his compatriots, Henri Lefebvre. ${ }^{3}$ At one point in The Production of Space Lefebvre defines 'texture' as a 'large space' (such as an urban landscape) articulated by a network of 'strong points' (monuments for example) (Lefebvre 1974/1997: 222). This accords with Barthes' (1997a: 167-8) view that cities are made up of a rhythm of strong/marked and neutral/unmarked signifiers. Like Barthes, Lefebvre (1997: 222) discounted the idea that monumental works have definite signifieds, but rather that they operate across a 'horizon of meaning'. Another similarity is Lefebvre's assertion that monumental works are 'acted’ rather than 'read' (cf. Burch 2005: 211-212).

To recap, then:

[T]he signifieds of objects depend a great deal not on the emitter of the message, but on the receiver, i.e., on the reader of the object... [T]he object is polysemous i.e., it readily offers itself to several readings of meaning; in the presence of an object, there are almost always several readings possible, and this not only between one reader and the next, but also, sometimes, within one and the same reader (Barthes 1988: 188). 
We can now begin to appreciate how the import of urban symbols differs over time and between users/readers. Take, for example, a signifier such as an imaginary commemorative monument. It will signify different things to different users/readers across a 'horizon of meaning' stretching from the sacred to the profane. Within that scale will be some users/readers for whom the monument was never more than a simple landmark, a neutral signifier - a mere 'stone in the landscape' (cf. Young 1993: 2-3). In addition, a once strong/marked symbol such as a flower-strewn memorial, a memorial to a politically contentious event or a statue of a politician who polarized opinion, could, in time, become a neutral/unmarked signifier - a neglected lump of stone whose commemorative association has been dimmed or broken.

Similarly, alterations to even non-commemorative monuments such as buildings trigger symbolic and well as spatial changes in the city texture. The demolition of one utilitarian monument and its substitution by an alternative building in a different scale, style or material impacts on those vestiges of the past that still feature on the urban scene. The latter might not have materially changed but its advancing age, sudden rarity, increasingly unusual appearance or progressively more anachronistic technologies transforms it into a signifier of 'heritage'. This in turn prompts certain users/readers to vociferously demand its protection and preservation in the face of the development lobby. The endless battle to shore-up ancient monuments against the ravages of time provides eloquent proof that 'use never does anything but shelter meaning' (Barthes 1997b: 174). Thus, whilst an object 'serves some purpose, it also serves to communicate information... [because] there is always a meaning which overflows the object's use' (Barthes 1988: 182).

Monuments are invariably built out of materials that are meant to endure such as metal and stone. But this contrasts markedly with what they signify. For, as Barthes 
(1997a: 169) reminds us, to interpret a monument 'is only to be a kind of witness to a specific state of the distribution of signification'. Monuments cannot therefore be 'read' in isolation: 'meaning is born not from an object, but from an intelligible assemblage of objects: meaning is in some sense extended' (Barthes 1988: 186). Extended not only across space, but through time as well.

For Barthes (1997a: 169), then, what is signified by an object has less to do with its content and more to do with its 'correlative position'. This led him to conclude that 'there is no object which escapes meaning' (Barthes 1988: 182). Even an unremarkable fast-food kiosk, in certain 'correlative positions', is well able to signify - as will shortly become clear. And this is why it is incorrect to say that a neglected monument, shifted to some obscure park, covered in graffiti and with its inscription obscured, is devoid of all meaning and has ceased to signify. Rather, the abandoned, vandalized statue on a pedestal 'signifies itself as non-signifying' (Barthes 1988: 188). It reveals that a change has taken place in society or in the perceived merits of the person or event that was once deemed worthy of commemoration.

This theory is played out in practice in the monuments which populate the town of Narva in eastern Estonia (Burch \& Smith 2007). One such - a statue of Lenin - has been awkwardly left in the corner of the castle courtyard following its removal from a pedestal in a main square. ${ }^{4}$ Nevertheless, it is still a signifier and it still signifies, albeit in a way scarcely imagined by its original proponents. Ironically enough it might well be argued that the displacement of the statue has had the paradoxical effect of rendering it more visible than if it were in its 'proper' or 'obvious' place. In this the Narva statue of Lenin serves to elucidate an important point well appreciated by Barthes (1988: 184), namely 'the obstacle of the obvious'. What objects 'mean' is seemingly self-evident - they just simply are. 
An excellent illustration of this is apparent when it comes to landscapes as a whole. In the introduction to their edited volume Landscapes of Defence, Gold and Revill (2000: 13) draw on the work of Stephen Daniels to address what they term 'the process of naturalization'. This refers to a landscape's 'ability to separate the sign from the practices that produce signification'. Gold and Revill elucidate this apparently complex idea by combining it with Don Mitchell's attempt to theorize the role the state plays in landscape production. Mitchell (cited in Gold \& Revill 2000: 13) suggests that:

Landscape is best understood... as a certain kind of produced, lived, and represented space constructed out of the struggles, compromises, and temporally settled relations of competing and cooperating social actors: it is both a thing and a social 'process', at once solidly material and ever-changing. Like a commodity, however, the evident (that is temporarily stabilized) form of landscape often masks the facts of production.

This is rendered doubly problematic when it comes to one particular feature of many urban landscapes: commemorative monuments such as statues or plaques. If they are noticed their very often protracted and contested genesis is invariably hidden. And anyway, all too often even their 'temporarily stabilized form' is overlooked. They are, as Robert Musil (1995: 61) put it, 'conspicuously inconspicuous. There is nothing in this world as invisible as a monument.' Their apparent immutability and formulaic appearance means that they are habitually ignored.

That said, however, even the most unremarkable statue, one that 'stand[s] around quietly, accepting occasional glances’ (Musil 1995: 63), is a latent signifier waiting for the right correlation of events at which point it will reveal itself capable of become a focus for attention or even a catalyst for insurrection. This final scenario affirms the 
fact that contemporary events alter the legacy of monumental signifiers from previous eras. This is most apparent during a sudden or violent change of political regime - and explains why effigies are toppled from their pedestals whenever a dictator is ousted from power.

Barthes (1988: 184) was therefore surely correct to recommend that the user/reader who wishes to study such objects ought to 'resort to an order of representations in which the object is presented in a simultaneously spectacular, rhetorical, and intentional fashion'. Such methods are deployed in the following analysis of the Baltic Exchange, an inadvertently commemorative monument that seems peculiarly well suited to an investigation of this kind. For, as Barthes (1988: 184) observed, 'if we are to study the meaning of objects, we must give ourselves a sort of shock of detachment'. When it comes to the Baltic Exchange building in the City of London, this 'shock of detachment' occurred in the most dramatic of fashions: a terrorist bombing.

\section{A brief history of the Baltic Exchange}

The origin of the name 'Baltic Exchange' can be traced back to the Virginia and Baltick coffee house on London's Threadneedle Street. ${ }^{5}$ The venue was given this title in 1744 prompted by the merchants and naval officers who met there to discuss trade with the North American colonies and then, when war in Europe made the Atlantic Sea too dangerous, the Baltic region. Goods from that area included tallows, oils, flax, hemp and seeds. In 1823 this gathering place became a subscription-based organization known as the 'Baltic Coffee House' or 'the Baltic Club'. Later, in 1892, a rival organization - the London Shipping Exchange - opened. The two merged in 1900 at which point a new company was incorporated: the Baltic Mercantile and 
Shipping Exchange Limited. Further takeovers occurred before, in 1903, the company moved to the purpose-built Baltic Exchange designed by the architects T. H. Smith and William Wimble.

This grandiose classical building was situated on St Mary Axe in the City of London. Its symmetrical façade featured giant order columns surmounted by a triangular pediment filled with allegorical sculpture (Figure 1). The principal feature was, however, the interior's large marble hall where the trading took place (Figure 2).

These international transactions were inevitably disrupted by the First World War. German members were banned and sixty-two people affiliated to the Exchange died in the conflict. Marble panels listing the names of the dead were inaugurated in 1920. Two years later an elaborate series of stained glass memorial windows were inserted above the staircase in the main hall.

The Baltic Exchange declined in importance after the First World War. The shift to the transportation of goods by airplane led to it becoming an air freight exchange in 1949, at which point the Baltic Airbrokers Association was formed. Postwar government controls on the shipping market were relaxed in 1952 and both membership and the building expanded: the foundation stone of an extension to the building was laid by Winston Churchill in 1955, with Queen Elizabeth II formally opening it the following year.

Even so, changes in technology such as improved communications lessened the need for face-to-face dealing. The trading hall became something an anachronism and the organization began to consider moving operations to a different site (Powell 2006: 20). Matters were taken out of their hands at 9:20pm on Friday 10 April 1992. This was the moment when a van, parked outside the Exchange and carrying 100 pound Semtex bomb wrapped in a ton of fertilizer, exploded. 


\section{April 1992 and after: terrorism}

This event had far-reaching consequences, the most immediate and devastating of which were the injuries inflicted on those unfortunate enough to be in the vicinity. Three people died as a result of the bomb attack. Their deaths serve as a reminder of the devastation wrought by years of conflict over the status of Northern Ireland. ${ }^{6}$

The group responsible for this and many other such attacks was the Provisional Irish Republican Army - the IRA. Members of the same organization planted another device in the adjacent Bishopsgate in April of the following year, again causing enormous damage and destruction but no loss of life. However, whilst the Baltic Exchange had been damaged but not destroyed, the same could not be said for the church of St Ethelburga on Bishopsgate. This tiny medieval building had escaped the Great Fire of London and the aerial bombing of the Second World War. It did not survive the IRA.

These two actions ushered in strict security measures and led to a so-called 'ring of steel' around the City of London. This is outlined in Jon Coaffee's contribution to the aforementioned book Landscapes of Defence. Coaffee (2000) lists some of the motivations behind the IRA's actions. Their main aim was to undermine the City of London as a financial capital. They also sought media attention for their cause something that could be realized by attacking 'prestigious landmark buildings' such as the Baltic Exchange (Coaffee 2000: 118).

The attack therefore had symbolic implications. It struck at what was once 'the commercial heart of the... British Empire' especially given that shipping was crucial to the idea of Britain once 'ruling the waves'. 7 This is vividly underscored by a visit to the 'Baltic Glass' display at the National Maritime Museum at Greenwich. ${ }^{8}$ There one can see the painstakingly restored memorial windows from the Baltic Exchange. 
Designed by John Dudley Forsyth (1874-1926) they center on a scene in a Roman temple where centurions welcome the winged figure of Victory as she steps ashore. The symbolism of the image and the fact that the temple is decorated with symbols of British territories overseas shows that a clear analogy is being drawn between the modern era and antiquity: London is the new Rome. Some Irish nationalists are of the opinion that the problems on the island of Ireland are a direct legacy of colonial occupation. Seen in this light the shattered glass of the Baltic Exchange acted as a powerful signifier of the conflict.

This example reveals the uncomfortable fact that iconoclasts - including terrorists conduct their own readings of the urban environment. ${ }^{9}$ The Baltic Exchange was primarily a functional utilitarian building, not a commemorative memorial. But, as Barthes reminds us, use always hides meaning - and sometimes meaning is only made clear at the moment something is destroyed.

This is an undeniable truth in the wake of the attack on the World Trade Center in New York. This, even more than the Baltic Exchange, was a symbol of trade and economic dominance. The terrorists 'read' this landscape and deliberately chose this building for the media attention it would bring. The first plane hitting one of the towers was a media magnet, ensuring that the second plane's approach would be captured on film. At the moment of its annihilation it became 'a pure signifier': 'the [Twin] Tower[s] attracts meaning the way a lightning rod attracts thunderbolts. ${ }^{10}$ The attack realized the iconicity of the building - and unfolded its signification in the most brutal of fashions.

At the precise moment that one iconic monument was being toppled another was being put up. This was 30 St Mary Axe by Foster and Partners, a 180 meter tall skyscraper that became an iconic 'symbol of London' almost as soon as it was 
completed in 2004 (Powell 2006: 195). Its designer - Norman Foster, Lord Foster of Thames Bank - describes it as 'a tremendous act of faith and confidence in the future' (cited in Powell 2006: 11). This was not only because the client kept their nerve to erect such a vivid landmark post-9/11, but also because this 40 storey structure was itself a product of a terrorist outrage. For 30 St Mary Axe is positioned on the very site of the wrecked Baltic Exchange. The heritage of the past was sacrificed for the heritage of the future when English Heritage (the British government's statutory adviser on the historic environment) concluded that the skyscraper was 'of such exceptional architectural interest that it would be a justifiable replacement for the Baltic Exchange' (Powell 2006: 46). However, as the following section shows, this decision was neither inevitable nor without controversy.

\section{April 1992 and after: heritage}

The building of 30 St Mary Axe would not have been possible without the bombing of 1992. This was because the Baltic Exchange was inscribed on a statutory list of buildings of 'special architectural or historic interest'. ${ }^{11}$ 'Listing' is a legal safeguard which, according to English Heritage, is 'not intended to fossilize a building' but to ensure that material changes that impact on the building are 'carefully considered before... [being] agreed.' Such deliberations were not considered by the IRA in 1992. Prior to that the Baltic Exchange had been listed, first in 1972 at Grade II and then at Grade II* in 1987. This latter category is reserved for 'particularly important buildings of more than special interest'. This was merited mostly on account of the interior. Indeed, the façade has been described as 'unexceptional' (Powell 2006: 15), whilst a survey of Victorian architecture published in 1987 described it as 'a grand classical building with a feebly small pediment' (Orbach 1987: 209). It is fair to say 
that the Baltic Exchange only rose to eminence because so many of the City of London's more significant Victorian and Edwardian buildings had been demolished in the 1960s and 1980s (Powell 2006: 15-17).

Nonetheless a pressing question prevailed: what should be done with the damaged remains of the building? One possible solution was to follow the precedent set by the church of St Ethelburga. This casualty of the 1993 blast was re-erected using those pieces of stonework, carpentry and stained glass which could be salvaged from the bomb site (Figure 3). ${ }^{12}$ A similar approach was taken elsewhere in the environs of this protected 'conservation area' where many façades have 'been subject to extensive repair and rebuilding in replica, thereby ensuring that its architectural character is maintained' (Rees 2000: 14).

However, the cost of such an undertaking when it came to the Baltic Exchange was prohibitive. In addition, no obvious use suggested itself for the outmoded building. The ensuing heritage debate has been extensively documented elsewhere (see e.g. Powell 2006; SAVE c.2000). However, it suffices to say here that it took eight years from 1992 until 2000 for the matter to be resolved and a further four until the replacement was complete. The protracted affair involved an array of interested parties - ranging from the original owners, property developers, the City of London Corporation, the Mayor of London, the Deputy Prime Minister, English Heritage, the campaigning group SAVE Britain's Heritage and the media - before the ultimate developer Swiss Re succeeded in commissioning Foster and Partners to build their opulent new headquarters.

One aspect of the controversy centered on the perceived impact that this skyscraper would have on the London skyline. Its opponents feared - quite correctly - that it would set a precedent for high-rise building in the capital. Those that are currently 
being constructed or planned include 122 Leadenhall Street by Richard Rogers (224m), Heron Tower (242m), Bishopsgate Tower (288m) and The Shard (310m). The last of these - 'The Shard of Glass' - by the Italian architect Renzo Piano will rise alongside London Bridge station. Its soubriquet and shape shows that it strives to be more than just a monolith on the landscape and that it craves the same sort of iconic status as that won by Norman Foster's 'gherkin', so-called on account of its unusual form.

What helped pave the way for these skyscrapers was the decision to allow the building of 30 St Mary Axe. It undoubtedly marked 'a watershed for new development in London' (Powell 2006: 47). A legacy of this is the recent decision to narrow the socalled 'Protected Vista Directions'. These are intended to safeguard the views towards such iconic structures such as St Paul's cathedral and the Houses of Parliament. ${ }^{13}$ The introduction to the policy document setting out the alterations to these vistas (written by Ken Livingstone, the Mayor of London) encapsulates the balance that needs to be struck between change and the status quo:

For London to remain a competitive world city, it must respond to the drivers of growth and continue to develop in a dynamic, organic manner without inappropriate restraints. At the same time, London is valued because of its first class heritage and historic landmarks that are cherished by Londoners and visitors to this great city. ${ }^{14}$

One person who believes that Britain's heritage is being decidedly undervalued is Prince Charles. In January 2008 he addressed the 'New Buildings in Old Places' conference to lament the ‘desecration’ of Britain’s UNESCO World Heritage Sites by buildings such as 30 St Mary Axe which 'pockmark [the] skyline’. ${ }^{15}$ 
The site of the Baltic Exchange was so important precisely because it was situated at the crux of this divide. It marked an important chapter in the long, open-ended record of London's conservation and eloquently confirms that any heritage is a result of 'the negotiation of diverse, conflicting interests and attitudes'. Heritage is always a 'highly contingent' affair shot through with politics (Hunter 1996: 16; Earl 1996).

\section{Cultural salvage}

Well before the construction of 30 St Mary Axe the stricken Baltic Exchange had been carefully dismantled with each piece being numbered and photographed before being taken from the site and offered for sale as a 'rich man's set of building blocks' ${ }^{16}$

It thus became a remarkable, although not exceptional, type of commodity. The preservation and reuse of old buildings is carried out in a number of ways and for a variety of reasons. One of these has already been illustrated, namely the rebuilding of St Ethelburga's church. There need not, however, be a direct correlation between the old and new structure. In Tallinn, for example, Ernst Kühert's reconstruction of Oleviste (the Black Heads') Guildhall (1919-21) includes window jambs from a $16^{\text {th }}$ century building that once stood on another part of Pikk street in the Old Town (Hallas 2000: 30). The adoption of older elements as a fascia for a new building can even extend to the retention of a whole façade. This point will be developed in the following section, but it suffices to say here that the decision to retain the original elevation is often driven by the desire to maintain a sense of place in sensitive conservation areas. This was the motivation behind the recreation of the Bishopsgate street scene following the bombing of 1993.

Even if old buildings are not re-erected in situ, they can be put up elsewhere. That the 'phenomenon of traveling salvages is not confined to recent times' is richly illustrated 
by John Harris (2007: 2) in his study into the widespread export of architectural salvage from Britain to the United States. In a similar vein, the concern to preserve representative examples of disappearing heritage can lead to the relocation of entire buildings. This was a pattern established by the Swede Artur Hazelius who founded Skansen in 1891 and paved the way for similar open air museums across Europe, including that which opened in Estonia in $1957 .{ }^{17}$

What might be termed ‘cultural salvage' (Connerton 2005: 316) has political drivers as well, as when artifacts are taken as signifiers of imperial or economic power. This accounts for why London, Paris and New York are all furnished with ancient Egyptian obelisks. They evoke the same sort of comparison between ancient and modern imperialism as that suggested by the stained glass memorial windows of the Baltic Exchange. It is therefore interesting that, when questioned about the relocation of the Baltic Exchange, the project manager Sander Pullerits chose to reflect that: 'The French once brought massive monuments over from Egypt. We're doing something similar. We are bringing a part of the Baltic Sea history back to Tallinn.' He was also reported as saying that ‘the building would stand as an icon of Tallinn's maritime history and its renewed economic success'. ${ }^{18}$

Pullerits could have gone on to add that the relocation of the Baltic Exchange also says a great deal about the changed geopolitical position of Estonia. A frequent refrain among many influential Estonians is that Estonia is at last 'back on the European map'. This is a phrase that features prominently in the booklet produced in support of Tallinn's successful bid to be a European Capital of Culture in 2011. This publication features a map of Europe in which Russia is occluded entirely. The Baltic Exchange, coming as it does from London, underscores the western orientation of this new EU member state. 
But what of the Estonian backers of the scheme? What might motivate them to spend $£ 800,000$ on acquiring the remains of the Baltic Exchange? The purchasers were two wealthy businessmen in their forties involved in the oil and shipping industries: Heiti Hääl and Eerik-Niiles Kross. The latter is the son of the late writer Jaan Kross. Thornton Kay, a partner in the salvage company that sold the Baltic Exchange, described Eerik-Niiles Kross as a former member of the Estonian secret service who represented Estonia at NATO negotiations. ${ }^{19}$ Kay speculated that Hääl and Kross:

see the rebuilding of the Baltic Exchange in Tallinn as a kind of bricks-andmortar political statement, establishing a feature building that not only creates another dimension to the architecture of Tallinn, much of which is Soviet, but also pointedly brings a physical part of the financial culture of the West bang up against the Russian border. ${ }^{20}$

Hääl and Kross intend to integrate the salvaged building into a new structure housing a restaurant, ballroom and offices. It has also been reported that they wish to collaborate with the Estonian Maritime Museum on an exhibition about the sea and trade.

This latter point indicates an awareness of the signifying potential of the Baltic Exchange. It also gives an insight into the ways in which the utilitarian functions of the building merge into its symbolic connotations. This affirms the truth of Barthes' (1988: 182) assertion that 'there is always a meaning which overflows the object's use'. Barthes chose to use the humble telephone to illustrate this point. Variations in color, design and age mean that there are telephones that connote 'luxury' or 'femininity'; 'there are bureaucratic telephones, there are old-fashioned telephones which transmit the notion of a certain period...; in short, the telephone itself is susceptible of belonging to a system of objects-as-signs' (Barthes 1988: 182). This 
provides the perfect explanation as to why two businessmen should have invested in the salvaged remains of a century-old building. For one of the fixtures included in the sale were the Baltic Exchange’s ornate telephone booths. One hundred years later in a digital and wireless Estonia these kiosks will surely be superfluous in purely utilitarian terms - but that does not mean they have ceased to carry meaning. Indeed, their unusual, anachronistic form and function indicate that meaning really has 'overflowed the object's use'. They promise to encapsulate the exotic appeal of the Baltic Exchange: it has the potential to offer something ‘authentically’ different.

\section{The Tallinn palimpsest}

In August 2007 it was reported that the Baltic Exchange would be built 'close to the port terminals' on a site that had apparently been chosen 'with the full support of Tallinn city'. ${ }^{21}$ This disguises the fact that the desired location was clearly a matter of some dispute.

The site favored by Hääl and Kross had been named in an article published in Eesti Ekspress in June, the same month that the building began to arrive in Estonia. ${ }^{22}$ The plot lay just outside the Old Town on an arterial road called Estonia pst. This is currently occupied by a modest single storey florist shop and a 24 hour fast-food kiosk. Of more architectural interest is the building facing it on the other side of the road. This would make the perfect foil to the London building. It dates from 1912-16 and is constructed in a Neo-Baroque style according to the designs of Aleksander Rosenberg, an engineer from St Petersburg. The central portion of the main façade is articulated by six giant order pilasters surmounted by a triangular pediment. This leads in to a double height hall. These similarities with the Baltic Exchange extend 
even to the function it serves: in 1996 it was converted into an English College (Hallas 2000: 42).

The aforementioned Eesti Ekspress feature was accompanied by a computergenerated montage of the proposed building showing the recycled façade of the Baltic Exchange with a much larger glass structure rising above it. Again this would chime with its surroundings: the building next door - designed by Henno Sillaste and dating from 1997-8 - is a wedge-shaped, seven storey office block (Hallas 2000: 42). Its ground-plan is dictated by the awkward triangular plot delineated by two thoroughfares. The elevation facing one of these is in granite, the other is an undulating wall of tinted glass.

Interestingly enough the form of the Baltic Exchange as suggested in the Eesti Ekspress image carries echoes of one of the early proposals for the original site in London. When it looked like the building was to be 'restored', the architectural practice GMW drew up an unrealized design for a 'groundscraper' dominating the 1903 façade (Powell 2006: 20).

This (albeit unrealized) scheme is just one further example of the ways in which traces of earlier buildings can sometimes remain in evidence even if a site has been comprehensively redeveloped. A clear instance of this occurs in relation to one of the most famous works of contemporary architecture: Richard Rogers' postmodern Lloyd's of London building on Lime Street (1981-86) not far from the site of the Baltic Exchange. The retention of the entrance to Sir Edwin Cooper's 1928 building on Leadenhall Street sets up a decidedly uncanny juxtaposition: a closer examination of the stone portal reveals that it is simply a screen through which can be seen the metal tubes of Rogers’ iconic design. 
The final architectural plan for the Tallinn version of the Baltic Exchange has not, as yet, been decided. Its ultimate appearance will, of course, play a large role in the meanings that can be drawn from it. This is important if one thinks back to what Barthes said about the interpretation of a sign. He said that 'the signifieds of objects depend a great deal not on the emitter of the message, but on the receiver'. The form and location underscore that, whilst meanings shift, they are rooted in specific contexts. To follow Barthes' approach means adopting a more rigorous, self questioning approach than that which presupposes there to be one 'truth' to be uncovered.

It is fitting therefore that this signifier will continue to unfold once the form has been decided and realized. This sense of unfurling will be especially apparent should the Baltic Exchange be built on the site suggested by Eesti Ekspress. This is because it would be in the environs of Freedom Square (Vabaduse väljak), an architecturally and symbolically sensitive area. And it is for exactly these reasons that planning permission might have been denied.

The importance of Freedom Square promises only to increase in the years leading up to 2011, the date when Tallinn will serve as a European City of Culture. Some $44.6 \mathrm{~m}$ EUR is earmarked for the redevelopment of what is 'Tallinn's central square and the venue for national parade events' (Haagensen 2007: 33). This quotation is taken from the above-mentioned brochure setting out the city's vision for 2011. It goes on to say that a new 'monument and memorial complex to commemorate the Estonian War of Independence' will be built there in 2008. The site will also be converted into 'an active leisure area' and transformed into 'an organic element of the "green belt" of the Old Town of Tallinn’ (Haagensen 2007: 33). 
Whether or not the Baltic Exchange merits being included on the fringes of this development will be determined through a process of negotiation between elected representatives, architects, big business, the heritage lobby and other spokespersons (cf. Hallas 2000: 19). Such a debate will bring the Baltic Exchange story full circle.

The fate of the Baltic Exchange will, then, in part at least, be determined by the current and future features of the cityscape. At present the whole southern side of Freedom Square leading to the proposed site for the Baltic Exchange is lined with buildings that are marked with plaques indicating that they are national monuments ('kultuurimälestis') together with individual registration numbers and the logo of the national heritage body.

As we have seen, being inscribed in this way is supposed to afford some protection from change. Processes of drawing up legislation for the preservation of the built heritage develop at a national level and at various speeds (Hunter 1996: 9, 114). This local scale is also overlaid with transnational protection, such as that bestowed by UNESCO via its designated World Heritage Sites. Tallinn was included on this list in 1998. This places the Estonian capital under international scrutiny, something that became painfully clear following the critical comments made by Giorgio Piccinato, a representative for the UNESCO World Heritage Committee who visited Tallinn in December 2005. ${ }^{23}$ He used the recent high-rise extension to the Viru Center to illustrate the necessity for 'an integral picture' which took into consideration the wider urban context. This, he argued, had not been heeded when it came to the Viru Center, which he slated for its adverse impact on 'the historical city’s silhouette'. ${ }^{24}$ The importance of such a skyline when it comes to heritage is evident from the aforementioned brochure promoting Tallinn as a future European cultural capital (Haagensen 2007: 4-5). Inside, a double page photograph shows the Old Town with 
its highly recognizable profile of church spires and eclectic low-rise monuments. This visualizes the symbolic potency - and economic importance - of its heritage. But, just as in London, this is always in conflict with demands for change and development - a perennial fight to maintain traditional appeal whilst also enabling growth and development.

Whilst there are, as in London, laws intended to protect the historically sensitive core from high-rise development, Tallinn faces some real challenges. A report in The Baltic Times in September 2007 cited the city’s chief architect, Endrik Mand as saying that 'there are no controls over building aesthetics' and that 'the council had little power to encourage or direct development, but relied on developers to drive the city’s future.' 25

A perfect illustration of this is provided by the recent fate of the Sakala Center. This complex on a prime location near the Estonia Theatre is praised in the guidebook to $20^{\text {th }}$ Century Architecture in Tallinn (Hallas 2000: 57). It notes the intriguing irony between its form and function: its ground-plan resembled that of a church, yet it served as the Political Education Center for the Estonian Communist Party. Its walls were built of rusticated limestone which, the guide says, can be seen as in keeping with the city’s Gothic churches. Meanwhile the interior decoration by Aulo Padar and Kristi Laanemaa ('the most stylish examples of Postmodernism in Estonia') was coupled with stained glass by Rait Prääts showing the ‘apotheosis of socialism’. It also notes an abortive plan to surmount the building's tower with a globe on which nation states were colored black or red according to whether they were capitalist or communist.

Despite being tainted by its Soviet associations this was clearly a signifier that could be praised for its aesthetic and historical qualities. Nevertheless, and despite the fact 
that it had found a new use as a cultural center, it was demolished shortly after the parliamentary elections in March 2007. ${ }^{26}$ Three months later contracts were signed to rebuild a new leisure complex at a cost of over 828 million kroons. ${ }^{27}$

This controversial event led many people to voice their criticism of the inadequate measures to protect the built heritage and a widespread perception that 'current development trends in Tallinn... allow anybody with money to buy their way past demolition controls and planning schemes.' This was a conclusion reached in an interesting newspaper article entitled 'Tallinn rediscovers Karp legacy' ${ }^{28}$ Its subject was 'the most loved and loathed architect in Estonia', Raine Karp. He was responsible for the Sakala Center (1982-1985) and other iconic late Soviet-era buildings such as Tallinn City Hall (1976-80), the National Library (1984-1992) and the Central Post Office (1975-1980). The article suggests that a resurgence of interest in these monumental structures is connected to a popular 'rejection of the recent inner-city building boom, which has seen a forest of skyscrapers spring up in the central business district.' They are criticized by the architectural historian, Andres Kurg on the grounds that these 'anonymous international style... glass and steel buildings' represent a threat to 'the identity of the city'. ${ }^{29}$

The discussion raised by the Sakala controversy serves as a reminder that care should be taken not to assume what is worthy of preserving and what is not. The very last Soviet tower block left standing - even should it be a much maligned serial type such as 'Soviet standard 1-464' - would become 'heritage'. Certain groups would demand its preservation in exactly the same sort of way as people protested at the removal of the Baltic Exchange and the building of 30 St Mary Axe.

This confirms Barthes' observation that everything can be meaningful and what matters is determined by a sign's 'correlative position'. Again, it is by unfolding the 
signifier that is the Baltic Exchange that this becomes clear. Take, for example, my photograph of the site proposed for the building (Figure 4). It depicts a decidedly unremarkable place. And yet, should this view make way for the Baltic Exchange, it would instantly become 'heritage' and worthy of being in an archive. And, even if the Baltic Exchange is not erected there, the image will continue to signify as a sign of a path not taken. It will be but one of the potential visions of Tallinn that were proposed but not realized. Investigating why it did not transpire will reveal something of the contested nature of the built environment.

The insertion of the Baltic Exchange will therefore alter the 'readings' of whatever part of the city in which it appears. This was apparent from an on-line discussion in July 2007 prompted by the prospect of the redevelopment and which led to an interesting discussion about the site. ${ }^{30}$ One of the participants opined: '[T]hat burgerplace is a real godsend at 5 am after clubbing! Any burger-place is! a) food b) drink c) last resort for scoring girls!' But he and his fellow discussants made such flippant remarks only after making a series of balanced and informed arguments for and against the siting of the Baltic Exchange on Estonia pst, its potential interaction with the adjacent English College, and the role of the National Heritage Board (Muinsuskaitseamet).

This exchange (sic) captures the lived sense of the city and its multitude of unrecorded narratives. Its users/readers were aware of planning issues and the history of the building, debating whether it would harmonize or jar with the existing streetscape. This was a working example of the 'rhythms' of the city texture as expounded by Barthes and Lefebvre.

The new Baltic Exchange will, then, provide a fresh layer in the palimpsest that makes up the history of Tallinn. With this in mind, some sense of disjuncture between 
the façade, the rest of the building and its surroundings is desirable. This will make it apparent that a fusion has taken place, prompting the city's users/readers to ponder why and thereby acknowledge, however unconsciously, that something interesting has taken place. This is likely to continue long after the origins of the building have been consigned to the history books.

Before turning to the final section, it is worth reiterating that the Sakala Center controversy and the realization that a burger bar or an undistinguished shop selling flowers can become signifiers in urban space serve as reminders that care needs to be taken to avoid assuming what is and what is not of value or meaning. In the case of a country such as Estonia this is a particularly pressing issue given its rich (sic) heritage of Soviet-era monuments. They raise many questions. What do they signify? Should they be preserved? Do they 'belong'?

\section{Wars of monuments}

Some of the flowers purchased from the florist on Estonia pst might well have been reverentially laid at 13 Kaarli Avenue, Tõnismägi. From September 1947 until April 2007 a 'Bronze Soldier' stood on this very spot. It is this sign which like no other addresses 'the functions of symbols in urban space'. It is the epitome of a signifier with multiple signifieds: to some it connotes liberation from fascism; for others it denotes Soviet occupation. It is able to signify more than one thing precisely because signifiers have multiple signifieds and because 'meaning' is cultural rather than given or 'natural' (Allen 2003: 119).

Moreover, the relocation of the Bronze Soldier confirms Barthes' point about the importance of context - or 'correlative position’ - to any given signifier. In April 2007 it was situated in a prominent location in the city center. The following month it 
had been moved to the more peripheral setting of a military cemetery. Although it appears unchanged it is not the same signifier. This is because '[a]ll we need to do is change the focus of a remark, of a performance, of a body, in order to reverse altogether... the meaning we might have given it' (Barthes 1977: 66). This gets to the heart of what Barthes (1977: 67) meant by ‘signification’ or the ‘degrees of language'. Beyond the literal, 'first-order meaning' of a sign are other, perhaps less obvious but frequently more revealing 'second-order meanings'. However, even if the latter is acknowledged, 'the original, first-order meaning is not completely forgotten' (Allen 2003: 44). This is useful to an understanding of both the Baltic Exchange and the Bronze Soldier: their relocations give rise to second-order meanings, but what they signified before has not been erased.

Both the protesters that gathered around the Bronze Soldier prior to its removal and the mourners who paid homage to it in its new setting are the embodiment of this fact. They took up Barthes' (1997a: 170, 172) call for them to make the city 'sing' rather actualizing their readings 'in secret'. Of course, the conjunction of singing and revolution has particular resonance for Estonians. A revolution of sorts took place in the streets of Tallinn on $27^{\text {th }}$ and $28^{\text {th }}$ April 2007. The protestors radically realized the reality of the built environment as they tore bits from the crumbling walls of Raine Karp’s nearby National Library and used them as missiles to rain down on the police. Again, this realized something that Barthes well understood:

The city, essentially and semantically, is the place of our meeting with the other, and it is for this reason that the centre is the gathering place in every city ... [T]he city centre is always felt as the space where subversive forces, forces of rupture, ludic forces act and meet (Barthes 1997a: 171). 
Is the rupture in Estonian society exposed by the Bronze Soldier destined to last forever?

Well, this is where the Baltic Exchange comes in as a positive symbol. Barthes said that each time he needed to 'test' or 'demystify' a message he 'subject[ed] it to some external instance' (Barthes 1977: 67). This is the motivation behind the paper you have been reading. I have taken advantage of the fact that the Baltic Exchange is currently in limbo between its old and new homes as an opportunity to use it as a lens by which to examine a range of Estonian issues associated to 'the functions of symbols in urban space’.

The Baltic Exchange offers the first glimpse of a way out of the Bronze Soldier morass. This is because it will be a quiet reminder that a 'war of monuments' is not unique to Estonia. The IRA have taken lives and they are also iconoclasts - targeting signifiers for their own purposes. The clearest example of the latter was provided by Nelson's Pillar in Dublin. This unfolding signifier was erected in the nineteenth century and blown up by the IRA in 1966 as a way of marking the fiftieth anniversary of the Easter Rising. Nelson’s decapitated head is today in Dublin Civic Museum. The trace of this absent signifier is forever felt in the Irish capital, especially now that its site is occupied by the monumental abstract form known as the Spire of Dublin.

The Baltic Exchange in Estonia will thus constitute a distant legacy of another sectarian conflict that has lulled but not been resolved. Two recent incidents testify to the fact that the Irish past - like the Estonian - is still contested. The first was the decision to move memorials to soldiers killed in Ulster placed at former military bases 'to more secure locations within the province and the British mainland' for fear that they would be defaced once the sites were decommissioned. The second concerns proposals to redefine the 'Ulster Troubles' as a 'war'. ${ }^{31}$ The terminology used to 
describe it, when it started, why and for what reasons are all highly disputed. Such is the way with all struggles of liberation and occupation. They give rise to conflicts which continue to be waged by subsequent generations in the form of 'history wars' (Dean \& Rider 2005: 44). The Bronze Soldier debacle is one manifestation of this schism, a legacy of a divided heritage between what in Western Europe is known as the Second World War of 1939-45, and in Russia is still today termed the 'Great Patriotic War' of 1941-45.

Meanwhile, another of the signifiers damaged in the Anglo-Irish 'war of monuments' - the tiny medieval church on Bishopsgate in the City of London - has been converted into the St Ethelburga's Centre for Reconciliation and Peace, an institution 'devoted to promoting understanding of the relationship between faith and conflict'. Might the Baltic Exchange serve some similar function? Well, it could start to do just this in 2011. In doing so it would resolve a problem identified by the chair of the Selection Panel for the European Capitals of Culture, Sir Robert Scott. In the autumn of 2007 he publicly criticized Tallinn's proposed program for 2011, declaring that it 'was “unclear in its European dimension”, lacked involvement from "new Estonians," and did not show any new examples of culture.' Others were critical of what they saw as an exclusive focus on the medieval Old Town. ${ }^{32}$

What better way of addressing these complaints than by launching the 2011 celebrations in the former trading hall of the Baltic Exchange? This re-erected monument could be promoted as a potent metaphor for heritage: that dynamic fusion of the past and the present. London's Baltic Exchange in Tallinn as an amalgam of old and new has the capacity to encapsulate the creative potential of heritage. It has, moreover, the wherewithal to demonstrate that something from the outside can be 
incorporated into - and enrich - the local milieu. And, finally, it goes without saying that the Baltic Exchange signifies across a decidedly European dimension.

\section{References}

Alas, Joel (2007a) 'Historic London building to be reassembled in central Tallinn', The Baltic Times, June 13, available at: www.baltictimes.com/news/articles/18054, accessed 6.2.2008.

Alas, Joel (2007b) 'Tallinn’s planning problems revealed', The Baltic Times, 26 September, available at: www.baltictimes.com/news/articles/18891, accessed 6.2.2008.

Alas, Joel (2007c) 'Tallinn rediscovers Karp legacy’, The Baltic Times, 31 January, available at: www.baltictimes.com/news/articles/17229, accessed 6.2.2008.

Alas, Joel (2007d) 'Tallinn "not ready” to be culture capital', The Baltic Times, 5 September, available at: www.baltictimes.com/news/articles/18704, accessed 6.2.2008.

Allen, Graham (2003) Roland Barthes (London and New York, Routledge).

Barthes, Roland (1988 [1964]) 'Semantics of the Object' in The Semiotic Challenge (translated by Richard Howard) (Oxford, Basil Blackwell), pp. 179-190.

Barthes, Roland (1990 [1973]) The Pleasure of the Text (translated by Richard Miller) (Oxford, Basil Blackwell).

Barthes, Roland (1997a [1967]) 'Semiology and the urban’ in Neil Leach (ed.)(1997) Rethinking Architecture: A Reader in Cultural Theory (London, Routledge), pp. 166172.

Barthes, Roland (1997b [1964]) 'The Eiffel Tower' in Neil Leach (ed.)(1997)

Rethinking Architecture: A Reader in Cultural Theory (London, Routledge), pp. 172180.

Beck, Lucy (2000) 'Collective amnesia', Peace Matters, 29, available at: http://www.ppu.org.uk/peacematters/pm2000/pm2000_33.html, accessed 6.2.2008.

Burch, Stuart (2005) 'The texture of heritage: a reading of the 750th anniversary of Stockholm', International Journal of Heritage Studies, vol. 11 (3), pp. 211-233.

Burch, Stuart \& Smith, David (2007) 'Empty spaces and the value of symbols: Estonia's “war of monuments” from another angle’, Europe-Asia Studies, September, Vol.59, No.6, pp. 913-936.

de Certeau, Michel (1984) 'Walking in the city' in The Practice of Everyday Life (translated by Steven Rendall) (Berkeley, California and London, University of California Press), pp. 91-110.

Coaffee, Jon (2000) 'Fortification, fragmentation and the threat of terrorism in the City of London', in Gold, J.R and Revill, G.E, Landscapes of Defence, pp. 114-129.

Cobley, Paul \& Jansz, Litza (2004) Introducing Semiotics (London, Icon Books).

Connerton, Paul (2005) 'Cultural memory’ in Tilley et al (2005) Handbook of Material Culture, pp. 315-324. 
Dean, David \& Peter E. Rider (2005) 'Museums, Nation and Political History in the Australian National Museum and the Canadian Museum of Civilization', museum and society, Vol. 3, No. 1, March, pp. 35-50.

Drayton, Michael (2007) 'Old world gives way to new as we make a Baltic exchange', Friday 17 August, available at:

www.lloydslist.com/ll/news/viewArticle.htm;jsessionid=D2222E4AC7A3096317F1F DB22EC780D2?articleId=1187276811668, accessed 6.2.2008.

Duncan, James S. (1990) The City as Text: The Politics of Landscape Interpretation in the Kandyan Kingdom (Cambridge, Cambridge University Press).

Earl, John (1996) 'London government: a record of custodianship', in Hunter, M (ed.) (1996), pp. 57-76.

Gold, John R. and Revill, G.E. (eds.) (2000) Landscapes of Defence (London, Addison Wesley Longman).

Haagensen, Michael (c.2007) Everlasting fairytale [2011 brochure]. Source: http://www.tallinn2011.ee/pdf/tallinn2011_eng.pdf, accessed 6.2.2008.

Hallas, Karin (ed.) (2000) $20^{\text {th }}$ Century Architecture in Tallinn (Tallinn, The Museum of Estonian Architecture).

Harris, John (2007) Moving Rooms: The Trade in Architectural Salvages (New Haven \& London: Yale).

Hunter, Michael (ed.) (1996) Preserving the Past: The Rise of Heritage in Modern Britain (Stroud, Alan Sutton).

Kindlam, Riina (2007) 'Sakala's last stand', 20 April, Eesti Elu (Tartu College Publishing Committee), available at: www.eesti.ca/main.php?op=article\&articleid= 15989\&PHPSESSID=fe0583f91ea1c7c9372a7b947f105971, accessed 6.2.2008.

Kurm, Kairi (2001) 'Tallinn mayor reveals dark underbelly’, The Baltic Times, 9 August, available at: www.baltictimes.com/news/articles/5300, accessed 6.2.2008.

Lane, Megan (2007) 'Extreme restoration', BBC News Magazine, available at: http://news.bbc.co.uk/1/hi/magazine/6230390.stm, accessed 6.2.2008.

Leach, Neil (ed.) (1997) Rethinking architecture: a reader in cultural theory (London, Routledge).

Lefebvre, Henri (1997 [1974]) The Production of Space (translated by Donald Nicholson-Smith) (Oxford, Blackwell).

Musil, Robert (1995 [1936]) 'Monuments' in Posthumous Papers of a Living Artist (translated by Peter Wortsman) (London, Penguin), pp. 61-64.

Onken, Eva-Clarita (2007) 'The Baltic States and Moscow's 9 May Commemoration: Analysing Memory Politics in Europe’, Europe-Asia Studies, 59, 1, January, pp. 2346.

Orbach, Julian (1987) Victorian Architecture in Britain (London, A \& C Black).

Peterkin, Tom (2008) 'Ulster Troubles “could be redefined as a war”', Daily Telegraph, 11 January, available at: http://www.telegraph.co.uk/news/main.jhtml?xml =/news/2008/01/09/nwar109.xml, accessed 6.2.2008.

Powell, Ken (2006) 30 St Mary Axe: A Tower for London (London, Merrell). 
Rayment, Sean (2007) 'Army forced to move Ulster memorials', Sunday Telegraph, 19 February, available at; www.telegraph.co.uk/news/main.jhtml?xml=/news/890 2007/02/18/ngrave18.xml, accessed 6.2.2008.

Rees, Peter Wynne et al (2000) St Helen's Conservation Area Character Summary (London, Corporation of London).

Tänavsuu, Toivo (2007) ‘Ärimehed toovad Londonist maja Tallinna’, Eesti Ekspress, available at: www.ekspress.ee/viewdoc/5D0BCDC1138A51B9C22572F00036476D, accessed 14 June 2007.

de Saussure, Ferdinand (1966 [1916]) Course in General Linguistics, edited by Charles Bally and Albert Sechehaye in collaboration with Albert Riedlinger, translated by Wade Baskin (New York, McGraw-Hill Book Company, 1966).

SAVE Britain's Heritage. (c.2000) The Baltic Exchange, Source: http://www.savebritainsheritage.org/baltic.htm, accessed 6.2.2008.

Tilley, Christopher; Keane, Webb; Kuechler, Susanne; Rowlands, Mike; Spyer, Patricia (eds.)(2005) Handbook of Material Culture (London, Sage).

Young, James E. (1993) The Texture of Memory: Holocaust Memorials \& Meaning (New Haven \& London, Yale).

\section{Endnotes}

${ }^{1}$ A very clear instance of this is Eva-Clarita Onken, 'The Baltic States and Moscow's 9 May Commemoration: Analysing Memory Politics in Europe', Europe-Asia Studies, Vol. 59 (1) 2007, pp. 23-46.

${ }^{2}$ What follows in this section is a very partial, superficial account that is skewed by the aims of this paper. The interested reader who is unfamiliar with the concept of semiology / semiotics might like to consult one of the many books outlining this 'valuable buzzword' (Cobley \& Jansz 2004: 3).

3 'Texture' suggests touch - and Lefebvre was keen to promote the idea that the world should be understood by all the senses, not just sight (see Leach 1997: 164).

${ }^{4}$ Olav Männi's statue of Lenin was originally placed on a pedestal designed by the architect Ilmar Bork. Erected in 1957 it was moved from the main square in 1993.

${ }^{5}$ Information on the history of the Baltic Exchange is derived from: 'History - The early years'. Source: http://www.balticexchange.com/default.asp?action

=article\&ID=388); and from the 'Baltic Glass' exhibition at London's National

Maritime Museum. Source: http://www.nmm.ac.uk/server/show/ConWebDoc.20025 (both accessed 6.2.2008).

${ }^{6}$ The three people that died in the bombing of 10 April 1992 were Paul Butt, aged 29 and a securities dealer; Thomas Casey, a 49 year-old doorman at the Baltic Exchange; and Danielle Carter, a 15 year-old schoolgirl. The devastation wrought by every death is summed up by the fact that one of the ambulance workers that arrived at the scene of the Baltic Exchange bombing never recovered from his experience. He shot his girlfriend five months later and tried to commit suicide. He is now in a secure psychiatric unit (Beck 2000). 
${ }^{7}$ Source: 'History - The early years'. Source: http://www.balticexchange.com/default .asp?action=article\&ID=388 (accessed 6.2.2008).

${ }^{8}$ Information on this is from Powell 2006: $50-1$ and 'Stained glass from the Baltic Exchange’, source: http://www.nmm.ac.uk/server/show/ConWebDoc.20025 (accessed 6.2.2008).

${ }^{9}$ This is not to overlook the fact that one of the main aims of the IRA and other terrorist organizations was to cause chaos and carnage with little care or understanding for life or property. Those responsible for the attack of April 1992 passed on misleading information to the police, indicating that the device was outside the Bank of England. This could have been a deliberate deception, or it might have been an indication that they were so poorly informed that they could not properly identify the buildings they were seeking to destroy.

${ }^{10}$ This deliberately skewed quotation is adapted from Barthes' brilliant article 'The Eiffel Tower' (Barthes 1964/1997).

${ }^{11}$ Information on listing is taken from http://www.englishheritage.org.uk/server/show/nav.1374 (accessed 6.2.2008).

12 The fact that two-thirds of the tower on the main west front facing Bishopsgate survived the bombing made restoration feasible. Much of the rest, however, needed to be built anew. See http://www.stethelburgas.org/ourhistory.htm (accessed 6.2.2008).

${ }^{13}$ See http://www.london.gov.uk/mayor/strategies/sds/spg-views.jsp (accessed 6.2.2008).

${ }^{14}$ See http://www.london.gov.uk/mayor/strategies/sds/docs/spg-views-final-all.pdf (accessed 6.2.2008).

15 'A speech by HRH The Prince of Wales at the New Buildings in Old Places Conference, St James’s Palace, London’ (31 January 2008). Source:

http://www.princeofwales.gov.uk/speechesandarticles/a_speech by hrh_the_prince_o f_wales_at the new buildings_in 604060620.html (accessed 6.2.2008).

${ }^{16}$ Pavilions of Splendour: 'The [dismantled] Baltic Exchange'. Source: http://www.heritage.co.uk/apavilions/baltic.html (accessed 6.2.2008).

${ }^{17}$ For an account of this within the wider context of Estonian ethnography, see Elle Vunder, 'Ethnography at the University of Tartu'. Source:

http://www.erm.ee/?node=130 (accessed 29.5.2008).

18 Joel Alas (2007) 'Historic London building to be reassembled in central Tallinn', The Baltic Times, June 13. Source: http://www.baltictimes.com/news/articles/18054 (accessed 6.2.2008).

${ }^{19}$ An article in The Baltic Times dated 9 August 2001 indicates that Kross was once 'a former coordinator of the work of the national security service with the State Chancellery'. It named him in connection with a controversial real estate deal involving the then mayor of Tallinn, Tonis Palts. See Kairi Kurm, 'Tallinn mayor reveals dark underbelly', The Baltic Times, 9 August 2001. Source:

http://www.baltictimes.com/news/articles/5300 (accessed 6.2.2008). 
${ }^{20}$ Cited in T.K. Salvo, 'Baltic Exchange sold to Estonia for $£ 800,000$ through an ad on SalvoWEB.com', 23 June 2007. Source:

http://salvonews.blogspot.com/2007/06/major-uk-architectural-salvage-deal.html (accessed 31.8.2007).

${ }^{21}$ Michael Drayton (2007) 'Old world gives way to new as we make a Baltic exchange’, Friday 17 August 2007. Source:

http://www.lloydslist.com/ll/news/viewArticle.htm;jsessionid=D2222E4AC7A30963 17F1FDB22EC780D2?articleId=1187276811668 (accessed 6.2.2008).

${ }^{22}$ Toivo Tänavsuu (2007) ‘Ärimehed toovad Londonist maja Tallinna’, Eesti Ekspress. Source: http://www.ekspress.ee/viewdoc/ 5D0BCDC1138A51B9C22572F00036476D (accessed 14.6.2007).

23 'UNESCO decries Viru Center', The Baltic Times, 7 December 2005. Source: http://www.baltictimes.com/news/articles/14172 (accessed 6.2.2008).

24 'Tallinn officials to provide UNESCO with explanation', The Baltic Times, 7 April 2006. Source: http://www.baltictimes.com/news/articles/15104 (accessed 6.2.2008).

${ }^{25}$ Joel Alas, 'Tallinn’s planning problems revealed', The Baltic Times, 26 September 2007. Source: http://www.baltictimes.com/news/articles/18891 (accessed 6.2.2008).

${ }^{26}$ Riina Kindlam, ‘Sakala’s last stand', 20 April 2007, Eesti Elu (Tartu College Publishing Committee). Source: http://www.eesti.ca/main.php?op=article\&articleid= 15989\&PHPSESSID=fe0583f91ea1c7c9372a7b947f105971 (accessed 6.2.2008).

${ }^{27}$ Source: http://www.merkoehitus.ee/?id=290 (accessed 6.2.2008).

${ }^{28}$ Joel Alas, 'Tallinn rediscovers Karp legacy’, The Baltic Times, 31 January 2007. Source: http://www.baltictimes.com/news/articles/17229 (accessed 6.2.2008).

${ }^{29}$ Kurg cited in Joel Alas, 'Tallinn rediscovers Karp legacy’, The Baltic Times, 31 January 2007. Source: http://www.baltictimes.com/news/articles/17229 (accessed 6.2.2008).

${ }^{30}$ See http://www.skyscrapercity.com/showthread.php?t=494989 (accessed 6.2.2008). The on-line discussion was triggered by the posting of a news story about the Baltic Exchange from the BBC's website: Megan Lane (2007) 'Extreme restoration', BBC News Magazine. Source: http://news.bbc.co.uk/1/hi/magazine/6230390.stm (accessed 6.2.2008).

${ }^{31}$ Sean Rayment (2007) 'Army forced to move Ulster memorials', Sunday Telegraph, 19 February. Source: http://www.telegraph.co.uk/news/main.jhtml?xml= /news/2007/02/18/ngrave18.xml (6.2.2008). Tom Peterkin (2008) 'Ulster Troubles "could be redefined as a war”, Daily Telegraph, 11 January. Source: http://www.telegraph.co.uk/news/main.jhtml?xml=/news/2008/01/09/nwar109.xml (accessed 6.2.2008).

32 Joel Alas (2007) 'Tallinn 'not ready' to be culture capital', The Baltic Times, 5 September. Source: http://www.baltictimes.com/news/articles/18704 (accessed 6.2.2008). 

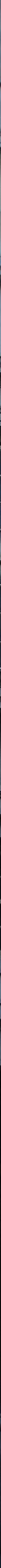


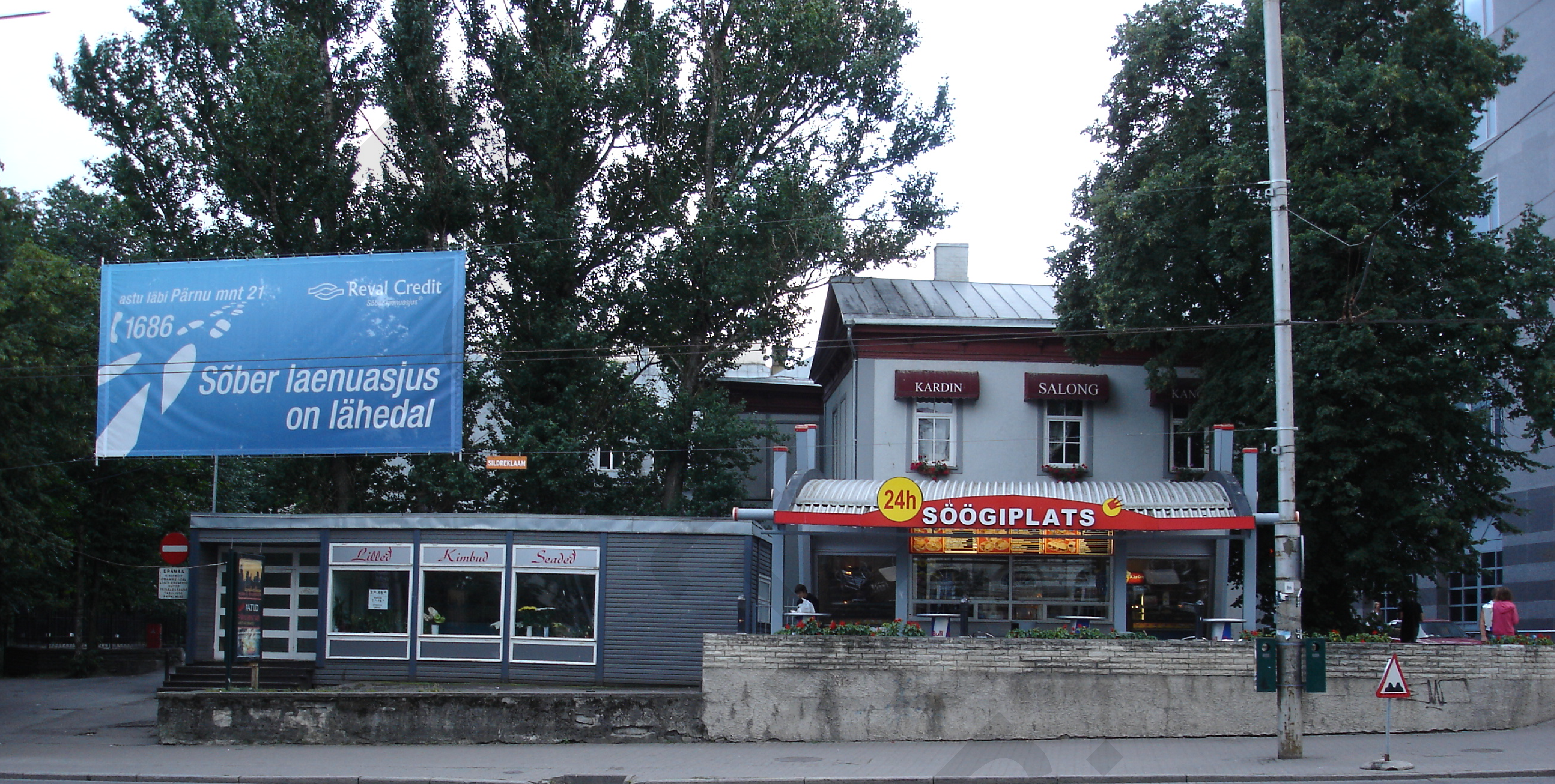

